\title{
Green Infrastructure Training for Veterans
}

\section{Ms. Carol L. Considine, Old Dominion University}

Carol Considine is the Assistant Dean of Outreach for the Batten College of Engineering and Technology at Old Dominion University (ODU) and an Associate Professor of Engineering Technology. She has a Bachelor of Science in Civil Engineering from Virginia Tech and a Master of Science in Civil Engineering from University of California, Berkeley. She has fifteen years of industrial experience as an estimator and project manager and is a LEED AP BD+C. She is a member of the NIST Community Resilience Panel, Building and Facilities Committee, served as the Private Infrastructure Chair for the Hampton Roads Intergovernmental Pilot Project and is a member of the Resiliency Collaborative at ODU. Her research interests include engineering education, industry collaboration, sustainability and resiliency.

\section{Mr. Michael W. Seek P.E., Old Dominion University}

Michael Seek is an Assistant Professor at Old Dominion University in the Civil Engineering Technology Program. He received a Master of Science and a PhD from Virginia Tech in Civil Engineering with a concentration in structures. He is a registered Professional Engineer in Virginia and has over 10 years of experience working as a structural engineering consultant on industrial and commercial projects. His primary teaching interest is in the area of structural mechanics and the design of concrete and steel structures. He has particular expertise in the design of cold formed steel structures and is the co-author of the Design Guide for Cold-Formed Steel Purlin Roof Framing Systems.

\section{Dr. Jon Lester, Old Dominion University}

Jonathan M. Lester is recognized regionally for his excellent reputation as both an educator and consulting Professional Engineer. He has served as a Lecturer for three years and as an Adjunct Professor for five previous semesters. His teaching contributions span a wide range of subjects from introductory courses, to required intermediate and upper level design electives. He has brought practical applications from consulting design and construction to the classroom that students' have found invaluable upon graduating. Serving as Experiential Learning Option advisor for multiple students' portfolios, Dr. Lester has successfully evaluated proposals from past work experience to grant course credit for distance students. He has served as the Civil-Site design option evaluator for Senior Design projects each semester as part of his normal teaching responsibilities. Dr. Lester has developed new courses in Civil Engineering Technology to better distribute the student load in Fluid Mechanics and the accompanying laboratory. Dr. Lester has also taught the Professional Engineering preparation courses through the ODU Business Gateway. Dr. Lester has embarked upon the initial asynchronous modality course development and was instrumental in promoting the program forward with this initiative with the Center for Learning and Teaching. He has developed an asynchronous course for Fundamentals of Building Construction and will develop several other courses in the future. Dr. Lester has over ten years' experience in the design and construction of general civil engineering projects in the Hampton Roads area. Consulting assignments have included wastewater collection projects as well as potable water distribution, utility rehabilitation and relocation projects, and storm water projects. He specifically has experience with sewer pumping stations; gravity sewer interceptors; water and wastewater treatment plants. Among his past project assignments are annual engineering services contracts with the cities of Norfolk, Virginia Beach, Suffolk, Radford, and Salem, VA. He is a Professional Engineer in the Commonwealth of Virginia and serves on the Virginia Water Environment Federation Stormwater Committee. He embodies the 'Citizen Soldier' concept that was instilled during his undergraduate studies at Virginia Military Institute, having served as a Marine Corps Reserve officer in addition to both his academic and professional endeavors for over twenty years.

\section{Dr. Anthony W Dean, Old Dominion University}

Dr. Anthony W. Dean has had several roles in academia. His previous appointments include Associate Professor of Engineering Technology and as Associate Director of the Institute for Ship Repair, Maintenance, and Operations at Old Dominion University (ODU). He is currently on assignment with the Office 
of the Dean for Sponsored Programs and the Engineering Fundamentals Department, Batten College of Engineering and Technology (BCET) at ODU. His research has focused mostly on control systems (integration and testing) and the reliability and maintainability of complex systems. He has been selected as both a NASA and an ONR Faculty Fellow. He regularly teaches courses in Marine Engineering and in Maintained Systems. Most recently Dr. Dean was on the Headquarters Staff the American Society of Naval Engineers. He received his Ph.D. from the Department of Engineering Management and Systems Engineering, and a B.S. in Nuclear Engineering Technology, from the Batten College of Engineering and Technology at Old Dominion University. Additionally, Dr. Dean received an MBA from the College of William and Mary. Prior to is academic career Dr. Dean was Director of Operations and Business Development for Clark-Smith Associates, P.C., and served as an Electrician in the US Navy aboard the USS South Carolina and the USS Enterprise. 


\section{Green Infrastructure Training for Veterans}

\section{Introduction}

The term green infrastructure has been in use for many years; however, the context of green infrastructure has changed significantly. Green infrastructure was originally a strategic approach to land conservation, and defined as an "interconnected network of green space that conserves natural ecosystem values and functions, sustains clean air and water and provides a wide array of benefits to human populations". While this is still an accurate description, the engineering community has adopted it to refer to stormwater techniques or practices that will capture, infiltrate and/or slowly release stormwater, which is the definition that will be used for this paper. The Environmental Protection Agency (EPA) refers to green infrastructure as natural vegetation, landscape design, and engineered techniques that retain, absorb, and often cleanse stormwater runoff. $^{2}$ There are multiple benefits to implementation of green infrastructure including reduction of stormwater runoff, therefore reducing demands on traditional gray infrastructure, restoration of natural hydrological cycles, ecosystem restoration, reduction of nutrients entering downstream surface waters as well as social and economic benefits. ${ }^{3}$

In 2011 the EPA launched a Strategic Agenda to Protect Waters and Build More Livable Communities through Green Infrastructure. This initiative supports local communities in using green infrastructure to manage rain water while creating co-benefits of green space, which makes communities more attractive and livable. ${ }^{4}$ In the fall of 2014 the Environmental Protection Agency along with the U.S. Department of Agriculture, U.S. Department of Defense, U.S. Department of Energy, U.S. Department of Housing and Urban Development, U.S. Department of the Interior and U.S. Department of Transportation signed a federal letter of support for green infrastructure recognizing it as an important tool for building resilience to climate change impacts such as increased heavy rainfall and heat island effect. Each agency committed to taking specific action to promote green infrastructure including but not limited to: creating alliances, providing community assistance, funding, training, development of metrics to assess performance of green infrastructure, and promotion of best practices. ${ }^{5}$

The City of Norfolk, the Green Infrastructure Center, Inc., and Old Dominion University have collaborated on a National Fish and Wildlife Federation Grant titled "Developing a Green Infrastructure Plan and Network for the Lafayette River Network". As part of the project Old Dominion University provided a training program to prepare veterans for the jobs in green infrastructure. Green infrastructure projects can provide business and employment opportunities for veterans. This project includes a 20 hour educational course for veterans to educate them about the green infrastructure industry, business and employment opportunities in green infrastructure and green infrastructure storm water management techniques. The program provides a base level certification that will qualify recipients for more advanced and specialized programs. The green infrastructure training certificate will be coordinated with other green infrastructure education certifications and programs in a "stackable" manner to provide a transparent track for career advancement, which will benefit employers and the green infrastructure industry.

\section{Green Infrastructure Demand}


Investment in green infrastructure is increasing and job opportunities in this field exceed the pool of skilled workers. Skilled workers are needed for landscape design and installation, landscape operations and maintenance and landscape supply chain. Jobs include landscape architecture, engineering, construction, urban planning, inspection, auditing, and horticulture.

Green infrastructure aids in climate resilience by managing flood risk, mitigating heat island impacts, mitigating drought through groundwater recharge, improving coastal resiliency and lowering energy demands for buildings and water management. ${ }^{6}$ Additionally it can help cities meet their urban runoff and pollutant load requirements by reducing the quantity of runoff and improving the quality of runoff into local waterways. Cities across the United States are investing in green infrastructure as a strategy to meet Clean Water Act requirements and build climate resiliency.

Examples of green infrastructure investment and jobs growth include:

- Philadelphia's proposed investment of $\$ 1.6$ billion in green stormwater infrastructure solutions over the next 20 years. This investment will create over 8600 jobs. $^{7}$

- District of Columbia Water and Sewer Authority has already invested more than $\$ 12.5$ million in green infrastructure and is planning on investing \$100 million in green infrastructure for the Potomac and Rock Creek watersheds. In addition, they have launched a green jobs training program to ensure access to trained maintenance staff. ${ }^{8}$

- The District of Columbia and Maryland are expected to spend over \$10 billion on stormwater management to clean up the Anacostia River over the next ten years. They are also investing in workforce training that includes credentialing and maintenance features. ${ }^{9}$

- The Department of Housing and Urban Development (HUD) recently awarded \$1 billion in grants through their National Disaster Resiliency Competition (NDRC). Approximately 60\% of the projects awarded included green infrastructure components. Those project awards were located in Connecticut, New York City, New Orleans, Tennessee and Virginia. ${ }^{10}$

\section{Green Infrastructure Training Course}

The green infrastructure training course for veterans developed for this project includes twenty hours of instruction: eleven hours of classroom instruction, a three hour green infrastructure tour, and a six hour implementation project. Descriptions of learning content is provided below:

Classroom instruction:

- Climate Change - focuses on the impacts of climate change in the southeastern U.S based on the National Climate Assessment. Focuses on key messages of sea level rise, including regional causes and impacts, increasing temperatures and associated problems, and water availability and associated problems

- Green Infrastructure Introduction - an explanation of green infrastructure, including elements, benefits, contribution to climate resilience, and differentiate between gray infrastructure and green infrastructure. 
- Green Infrastructure Industry - describes green jobs and green job growth, highlights investment in green infrastructure and job impacts from investment, outlines entry barriers for green infrastructure jobs and wages.

- Science of Green Infrastructure - review of the hydrologic cycle, provide descriptions of green infrastructure practices and how they are implemented, describe the impacts of development on watersheds and how green infrastructure practices can mitigate development impacts.

- Maintenance of Green Infrastructure - identifies the maintenance needs of green infrastructure practices and describes basic maintenance steps.

- Site Selection Introduction - describes parameters used in selecting a site for green infrastructure implementation, and parameters for selecting location for specific green infrastructure practices.

- Plant Selection - explanation of plant selection for various green infrastructure practices including rain gardens, buffers, wetlands, green roofs and permeable pavers, highlighting acceptable and unacceptable installation practices. Included acceptable plant materials for Hampton Roads region.

- Wetlands - review of the science and benefits of wetlands, differentiating between coastal and inland wetlands, explanation and description of constructed wetlands and evaluation of their application, and identification and control of invasive species.

- Site Assessment - hands on exercise using on-line site assessment tool focusing on evaluation of three areas - water quality impacts, retaining stormwater on property and watershed and wildlife friendly landscaping.

- Materials/Implementation Projects - description of rain barrel installation and demonstration of process. Overview of implementation project including location, requirements, planting plan.

Green Infrastructure Tour: tour of various green infrastructure projects in City of Norfolk. Tour included rain gardens, wetlands, buffer plantings and the rain garden implementation site.

Rain Garden Implementation Project: preparation of and planting of rain garden at Norview Elementary School. The completed project shown in Figure 1. 


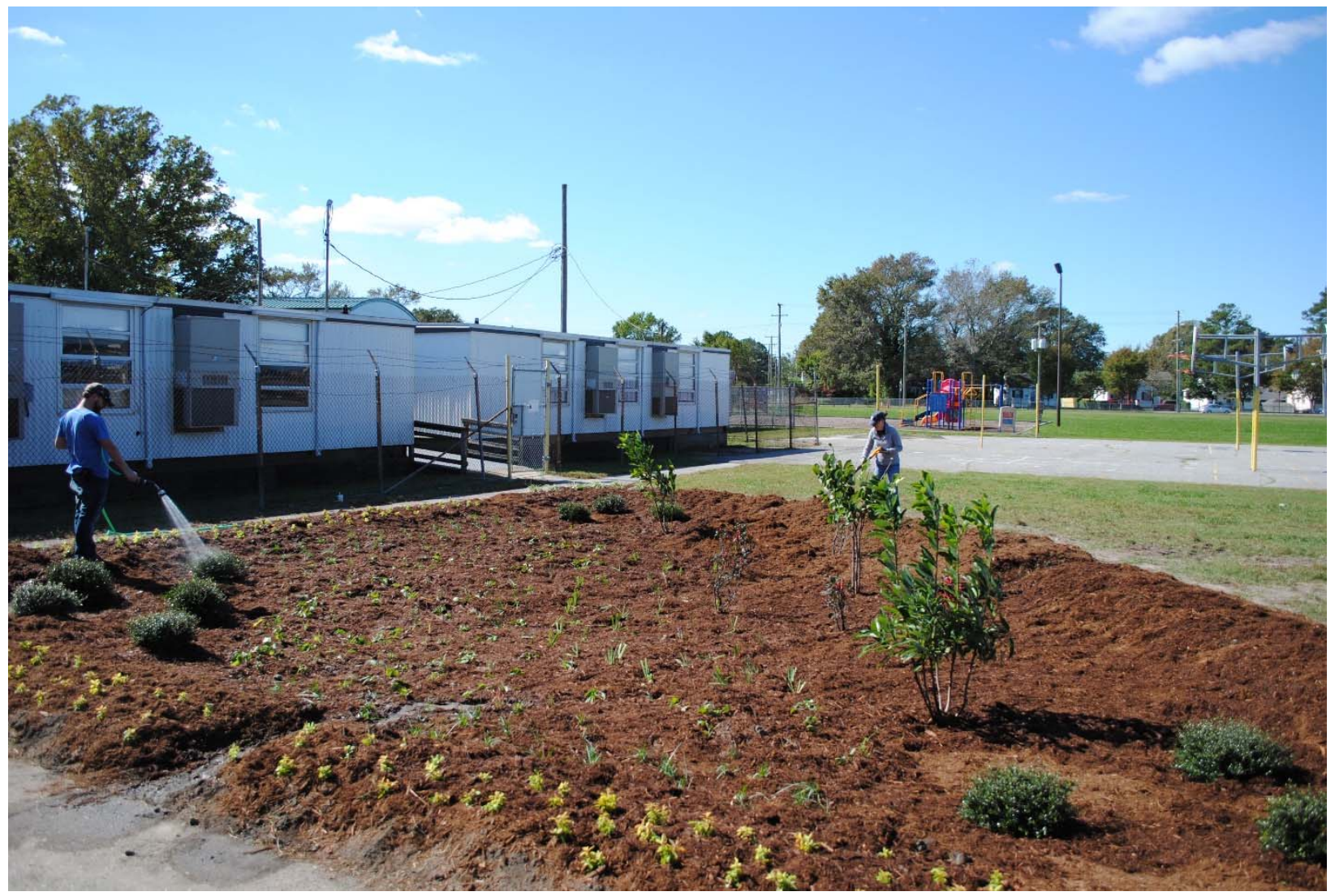

Figure 1. Rain garden implementation project.

\section{Participant Assessment of Green Infrastructure Training Course}

Upon completion of the course, participants were asked to evaluate the course content. The evaluation was based on a 5 point scale: very poor (1), poor (2), fair (3), good (4), very good (5). Results are shown below in Table 1.

Table 1. Participant Assessment of Green Infrastructure Training Course

\begin{tabular}{|l|c|}
\hline $\begin{array}{l}\text { Green Infrastructure Learning } \\
\text { Content }\end{array}$ & $\begin{array}{c}\text { Average } \\
\text { Score }\end{array}$ \\
\hline Course Overview & 4.9 \\
\hline Why Green Infrastructure & 4.9 \\
\hline Green Infrastructure Introduction & 4.9 \\
\hline Green Infrastructure Industry & 4.9 \\
\hline Green Infrastructure Science & \\
\hline \multicolumn{1}{|c|}{ Science of Green Infrastructure } & 4.7 \\
\hline Wetlands & 4.6 \\
\hline Green Infrastructure Tour & \\
\hline
\end{tabular}




\begin{tabular}{|l|c|}
\hline Green Infrastructure Site Tour & 4.4 \\
\hline Plant Selection & 3.9 \\
\hline Plant Selection & 4.4 \\
\hline Site Selection Introduction & \\
\hline Site Selection/Project & 4.8 \\
\hline Site Selection/Analysis & 4.7 \\
\hline $\begin{array}{l}\text { Maintenance of Green } \\
\text { Infrastructure }\end{array}$ & 4.7 \\
\hline Implementation Projects \\
\hline
\end{tabular}

Nine training participants provided feedback on the course training materials. All topic content was rated between good and very good with average scores between 4.4 and 4.9, except plant selection, which was rated at 3.9. The plant selection topic will be modified to provide additional background material for a novice in the field, including basic types of plants for the next course offering based on student feedback. Additional student comments are as follows:

- "I think this was an extremely informative workshop! Grateful for the information and the resources. Helped further an interest I had."

- "A lot of good information, little overwhelming but with a little bit more reading into topics will be better to understand."

- "Excellent course, very informative and increased awareness of urban development. Impact effect on environment. Would like to know if there is a bit more "science" behind plant/soil selection and the amount of runoff/water that could be absorbed. Overall I really enjoyed the class and have plans/ideas of how to implement green infrastructure in the near future and for life."

- "I will use this in my career and everyday life."

Participants were surveyed before the first training class and at the end of the training but before the rain garden installation project about their understanding of climate change, green infrastructure, plant selection and the impacts of development on stormwater. Fourteen students participated in the pre-training survey and eight students participated in the post-training survey. As seen in Table 2 below, their understanding in each of these areas improved with the largest improvement in the areas of green infrastructure and plant selection.

Table 2. Green Infrastructure Veteran Knowledge Questionnaire Results

\begin{tabular}{|l|c|c|}
\hline Green Infrastructure Veteran Knowledge Questions & $\begin{array}{c}\text { Pre } \\
\text { Training }\end{array}$ & $\begin{array}{c}\text { Post } \\
\text { Training }\end{array}$ \\
\hline How informed do you feel about climate change in the southeast United States? & 2.5 & 3.4 \\
\hline $\begin{array}{l}\text { I have a basic understanding of the causes of sea-level rise in the Hampton } \\
\text { Roads area. }\end{array}$ & 3.0 & 3.6 \\
\hline I can explain what green infrastructure is to my friends. & 2.5 & 3.9 \\
\hline I can outline 3 benefits of green infrastructure. & 2.5 & 3.9 \\
\hline
\end{tabular}




\begin{tabular}{|l|c|c|}
\hline $\begin{array}{l}\text { I can give you examples green infrastructure employment and business } \\
\text { opportunities. }\end{array}$ & 2.2 & 3.6 \\
\hline $\begin{array}{l}\text { I can describe 3 elements/examples of green infrastructure techniques for } \\
\text { stormwater management. }\end{array}$ & 2.1 & 4.0 \\
\hline I have applied or installed green infrastructure techniques in the last six months. & 1.9 & 3.3 \\
\hline I can identify basic maintenance requirements for green infrastructure projects. & 2.0 & 3.9 \\
\hline I can choose appropriate plants for a rain garden in the Hampton Roads region. & 1.7 & 3.3 \\
\hline I can evaluate a site for implementation of green infrastructure practices. & 1.8 & 3.4 \\
\hline Do you understand the impacts of development on stormwater? & 2.4 & 3.8 \\
\hline Do you think green infrastructure can be implemented in an urban environment? & 2.6 & 3.9 \\
\hline
\end{tabular}

Four general evaluation questions about the training course were asked. Eight students participated in the post-training survey the results are shown in Table 3. The scale used for the evaluation was strongly agree (5), agree (4), neither agree or disagree (3), disagree (2), and strongly disagree (1). The results indicate that participants felt that they benefitted from the workshop and overall the workshops was informative. Additionally participants felt the workshop was well organized and were happy with the use of Eventbrite for registration.

Table 3. Green Infrastructure Veteran Training General Evaluation Results

\begin{tabular}{|l|c|}
\hline Green Infrastructure Training General Evaluation Questions & Average \\
\hline Overall the workshop was informative. & 5.0 \\
\hline I have benefitted from the workshop. & 4.9 \\
\hline The workshop was well organized. & 5.0 \\
\hline Using Eventbrite for registration worked well. & 4.9 \\
\hline
\end{tabular}

\section{Future Plans for Green Infrastructure Training Course}

While the first offering of the Green Infrastructure Training for Veterans was successful, the following modifications are planned to improve the course:

- Modifications will be made to the planting module content to address student comments.

- Enrollment in the course was low and not all student that enrolled started the course and some started the course, but did not finish the course. To ensure that students who register actually follow through and take the course, we plan to include a nominal registration fee for future offerings.

- A new location for the training has been obtained to increase allowable enrollment in the course and improve logistics.

A second offering of the training course is scheduled for March 7 through March 18, 2017. The goal is to have 36 participants complete the March offering to exceed the total of 40 total participants in the training course. 


\section{Coordinated Education Programs}

The Green Infrastructure Training for Veterans is an introductory level course. The course has been coordinated with the Chesapeake Bay Landscape Professional (CBLP) Certification Program, which is a credentialing systems for professionals who design, install and maintain sustainable landscapes. The CBPL program launched a pilot program in 2016 and includes two levels of registration. Both levels of registration include credential training and examination on a core set of standards. The CBPL program is focused on the Chesapeake Bay Watershed and includes Virginia, Maryland, Pennsylvania and the District of Columbia. ${ }^{11}$ The coordination of these programs provides a transparent track for career advancement, in a stackable manner, which will benefit employers and the green infrastructure industry. Participants from the Green Infrastructure Training for Veterans course are being encouraged to enroll in the Chesapeake Bay Landscape Professional Certification Program. These programs will allow veterans to transition rapidly into the green infrastructure employment field and seek out positions in the area of green infrastructure.

\section{Conclusion}

Green infrastructure is seen as a solution for the growing storm water demands and provides additional benefits in terms of climate resiliency. Educating veterans on the opportunities for careers in this growing field can improve veteran outcomes and help them transition rapidly into this employment field. Participants in this training program found the program informative and indicated that they benefitted from the program. Long term goals of the program include developing employment opportunities and stacking the program with the CBLP certification program to aid veterans in overcoming traditional education barriers. 